\title{
DEVELOPMENT AND VALIDATION OF HPTLC ASSAY METHOD FOR SIMULTANEOUS QUANTIFICATION OF HYDROCORTISONE AND CLOTRIMAZOLE IN CREAM AND APPLYING FOR STABILITY INDICATING TEST
}

\author{
GETACHEW GENETE ${ }^{a}$, ARIAYA HYMETE ${ }^{a}$ AND ADNAN AHMED BEKHIT ${ }^{a \& b *}$
}

aPharmaceutical Chemistry Department, School of Pharmacy, Addis Ababa University, Addis Ababa, Ethiopia

${ }^{b}$ Pharmaceutical Chemistry Department, Faculty of Pharmacy, Alexandria University, Alexandria 21521, Egypt

(Received: December 1, 2010 - Accepted: May 23, 2012)

\begin{abstract}
A simple, specific, precise and accurate simultaneous high-performance thin-layer chromatographic method of analysis for hydrocortisone and clotrimazole was developed and validated. The method employed HPTLC glass plates $(20 \mathrm{x} 10) \mathrm{mm}$ precoated with silica gel $60 \mathrm{~F}_{254}$ as the stationary phase. The solvent system consisted of Toluene: Propanol: Ammonia (13:3:0.1v/v) that gave compact spots with $\mathrm{R}_{\mathrm{f}}$ value of $0.27 \pm 0.01$ and $0.58 \pm 0.02$ for hydrocortisone and clotrimazole, respectively. Densitometric analysis of hydrocortisone and clotrimazole was carried out in the absorbance/reflectance mode at $226 \mathrm{~nm}$. The calibration curves showed good linear relationship with $\mathrm{R}^{2}=0.996 \pm 0.003$ and $0.996 \pm 0.002$ in the concentration range of 200-1200 and 200-1000 ng/ $\mu 1$ for hydrocortisone and clotrimazole, respectively. The method was validated for precision, recovery and robustness. The LOD \& LOQ were found to be $35.31,107.01$ and $34.93,105.87$ $\mathrm{ng} / \mu \mathrm{l}$ for hydrocortisone and clotrimazole respectively. Statistical analysis proved that the method is repeatable, specific and accurate for the estimation of the studied drugs. Resolution of hydrocortisone, clotrimazole and their degradation products formed under different stress conditions (acid-base hydrolysis, oxidation and thermal degradation) was successfully achieved with the developed method indicating that it can be employed as a stability indicating method.
\end{abstract}

Keywords: Hydrocortisone; Clotrimazole; HPTLC method; Validation; Stability indicating

\section{BACKGROUND}

Hydrocortisone (cortisol); 11,17,21-trihydroxypregnan-4-ene-3,20-dione, the main physiologic glucocorticoid in humans has an anti-inflammatory and an immunosuppressive effect besides its role on carbohydrate and protein metabolism $^{1-3}$. The anti-inflammatory effect of hydrocortisone is due to reduction of histamine release, reduction of $\operatorname{IgG}$ production and decreasing of the activity of neutrophils and macrophages ${ }^{4-6}$. Clotrimazole; 1-(o-chloro$\alpha, \alpha$-diphenylbenzyl)imidazole is an imidazole derivative with antimycotic activity that is known to inhibit cytochrome P-450, ergosterol biosynthesis, and proliferation of cells and to interfere with cellular $\mathrm{Ca}^{2+}$ homeostasis ${ }^{7-9}$.
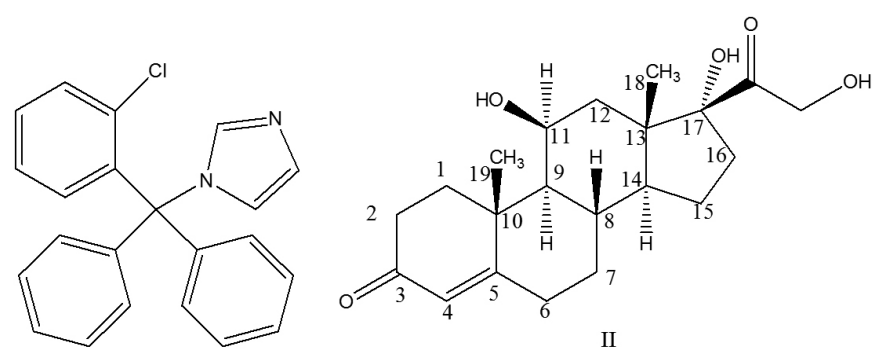

I

Fig.1: Chemical structures of clotrimazole (I) and hydrocortisone (II)

Various methods are available for the analysis of the two drugs in the literature separately; hydrocortisone; UV-spectrophotometer ${ }^{10}$, HPLC ${ }^{11-14}$, $\mathrm{TLC}^{13}$ and LC-MS/MS ${ }^{15}$; clotrimazole; UV-spectrophotometer ${ }^{16}$, Titration ${ }^{17}$, HPLC \& TLC ${ }^{13}$. However, there is no report on analytical methods for the determination of hydrocortisone and clotrimazole simultaneously and that resolve the degradation products from the parent drugs. An ideal stabilityindicating method is one that resolves its degradation products from the parent drug. Nowadays, HPTLC is becoming a routine analytical technique due to its advantages $^{18}$. The major advantage of HPTLC is that several samples can be run simultaneously using a small quantity of mobile phase unlike HPLC; thus lowering analysis time and cost per analysis, the method of detection does not place any restriction on the choice of the mobile phase and is environmental friendly. The aim of the current work was to develop and validate stability indicating HPTLC densitometric method for the simultaneous determination of hydrocortisone and clotrimazole in cream.

\section{EXPERIMENTAL}

\subsection{Materials}

The reference material of hydrocortisone (Batch No.:07012, Assay: 99.64\% and exp/date: 08/11) and clotrimazole (Batch No.:200803110117, Assay: $100.2 \%$ Mfg. date: 03/2008 and exp/date: 03/13) were kindly donated by the Drug Quality Control and Toxicology Laboratory of Ethiopia.

The dosage form candacort cream used (Batch No. 0949A805, Mfg date: 10/08, exp/date: 10/11) was manufactured by HOE Pharmaceutical, Malaysia. Each gram of the cream contained $10 \mathrm{mg}$ each of hydrocortisone and clotrimazole.

Cyclohexane, Diethyl ether, Hydrochloric acid and Sodium hydroxide (Sigma Aldrich, Germany), HPLC grade n-Hexane and Ammonia (Fisher scientific, UK), HPLC grade Ethyl acetate and Hydrogen peroxide (BDH, England), Glacial acetic acid and Dichloromethane (Fluka, Germany), HPLC grade Methanol (Scharlau chemie, Germany), Toluene (Acros organics, USA), 1-Propanol (Fluka, Switzerland) and Water (Double distilled) were used.

2.2.Preparation of standard solutions

Hydrocortisone and clotrimazole reference standards ( $100 \mathrm{mg}$ each) were weighed and transferred to a class-A $100 \mathrm{ml}$ volumetric flask and dissolved in $50 \mathrm{ml}$ of HPLC grade methanol with the aid of ultrasonication for 10 minutes. It was diluted to volume with the same solvent to obtain a concentration of 1 $\mathrm{mg} / \mathrm{ml}$ of each of hydrocortisone and clotrimazole. This solution was used as stock solution. Two concentration levels of standard solutions were prepared by diluting 10 and 20 times using methanol as a diluent.

2.3. Preparation of test solutions

The content of five tubes was mixed and $1 \mathrm{~g}$ of the cream containing 10 $\mathrm{mg}$ of each of clotrimazole and hydrocortisone was taken into a $100 \mathrm{ml}$ conical flask. $40 \mathrm{ml}$ of methanol was added and the cream was allowed to melt by warming at $60^{\circ} \mathrm{C}$ in a water bath with constant shaking. The melted cream was allowed to cool to room temperature. The warming and cooling process was repeated for two more times. The cream layer was allowed to solidify by keeping in the freezer for about 30 minutes.

The liquid portion of the melted cream was transferred quantitatively in to a class-A $100 \mathrm{ml}$ volumetric flask and diluted with methanol to volume. A portion of the mixture was centrifuged and applied on the HPTLC plate for development.

2.4. Instrumentation and chromatographic condition

The samples were spotted in the form of bands having a width of $6 \mathrm{~mm}$ with a $100 \mu \mathrm{l}$ Camag sample (Hamilton, Bonaduz, Switzerland) syringe on aluminium backed precoated silica gel $60 \mathrm{~F}_{254}(20 \mathrm{~cm} \times 10 \mathrm{~cm})$ with $250 \mu \mathrm{m}$ thickness plate (Merck, Germany) using a Camag Linomat V applicator $10 \mathrm{~mm}$ from the bottom and $20 \mathrm{~mm}$ from the side edges of the plate. The slit width was 
kept at $6 \mathrm{~mm} \times 0.45 \mathrm{~mm}$. The mobile phase consisted of Toluene:1-Propanol: Ammonia (13:3:0.1 v/v/v) and $25 \mathrm{ml}$ of mobile phase was used for development while $10 \mathrm{ml}$ of mobile phase was used for saturation. Linear ascending development was carried out in ADC2 $20 \mathrm{~cm} \times 10 \mathrm{~cm}$ twin trough glass chamber (Camag, Muttenz, Switzerland). The optimized chamber saturation time for mobile phase was $25 \mathrm{~min}$. The distance covered by the solvent front was $8 \mathrm{~cm}$ which took about 16 minutes. TLC plates were dried with a drier found in-situ at ADC2 chamber for 17 minutes. Densitometric scanning was performed on Camag TLC scanner III in the reflectance/absorbance mode at $226 \mathrm{~nm}$ for all measurements and operated by winCATS software (V 1.4.0, Camag, Muttenz, Switzerland). Evaluation was via peak areas with linear regression.

2.5. Method validation

The method was validated in compliance with ICH guidelines ${ }^{19}$ using the following parameters.

\subsubsection{Linearity, LOD and LOQ}

A stock solution of the synthetic mixture containing $1 \mathrm{mg} / \mathrm{ml}$ of each of hydrocortisone and clotrimazole was prepared. This solution was diluted ten and twenty times to obtain a working solution of $0.1 \mathrm{mg}$ and $0.05 \mathrm{mg} / \mathrm{ml}$ respectively. $1-20 \mu 1$ from $0.1 \mathrm{mg} / \mathrm{ml}$ in $1 \mu 1$ difference and $1 \mu \mathrm{l}$ from 0.05 $\mathrm{mg} / \mathrm{ml}$ of the working solution were applied on the HPTLC plate and the chromatograms were developed. Calibration graphs using the data obtained were plotted. Regression equation, correlation coefficient, y-intercept and value of slope were obtained from the calibration curve. Signal/noise ratios of 3.3:1 and 10:1 were considered as limits of detection and quantification respectively.

2.5.2 Precision

2.5.2.1 Intra-day precision

A stock solution of the synthetic mixture containing $1 \mathrm{mg} / \mathrm{ml}$ of each of hydrocortisone and clotrimazole was prepared. This solution was diluted ten times to obtain a working solution of $0.1 \mathrm{mg} / \mathrm{ml}$. Spot areas, in the given linearity range were obtained three times with in a day and the relative standard deviation of the peak responses at each level was calculated.

2.5.2.2 Intermediate precision

The intermediate precision of the method was checked by considering the effect of analyst variation and by comparing the average responses which were obtained in three different days. Results were reported as RSD.

2.5.3 Recovery

Recovery studies were carried out by spiking three different known amounts of the studied substances to the dosage form (standard addition method). The recovered amount of the drug substance was evaluated by using the regression equation obtained during determination of the linearity range.

2.5.4 Specificity

Peak purity of hydrocortisone and clotrimazole was assessed to evaluate the specificity of the method. The spots of the dosage form was scanned at three different levels, i.e., peak start (S), peak apex (M), and peak end (E) positions. The correlations between these spectra were compared.

2.5.5 Robustness study

The robustness of the method was examined by introducing small changes on the composition of the mobile phase. Variation by $\pm 10 \%$ was done to one of the components of the mobile phase while keeping amount of the others constant. Time from spotting to development and from development to scanning was varied to $5,15,20,40$ and 60 minutes. Robustness of the method was determined at $500 \mathrm{ng} / \mathrm{spot}$ level for both hydrocortisone and clotrimazole. The $R_{f}$ value of the spots and standard deviation of the response were examined and compared with the values considered as a reference.

2.6. Forced degradation of the drug substance

A stock solution containing $1 \mathrm{mg} / \mathrm{ml}$ of each of hydrocortisone, clotrimazole and synthetic mixture was prepared and used for forced degradation study.

2.6.1 Preparation of acid and base induced degradation products

To $20 \mathrm{ml}$ each of the stock solutions of hydrocortisone, clotrimazole and synthetic mixture; $5 \mathrm{ml}$ of $1 \mathrm{~N} \mathrm{HCl}$ and $5 \mathrm{ml}$ of $1 \mathrm{~N} \mathrm{NaOH}$ were added separately. These mixtures were heated under reflux for $8 \mathrm{hr}$ at $80^{\circ} \mathrm{C}$. The resultant solution was applied on to HPTLC plate at $500 \mathrm{ng} / \mathrm{spot}$ level and the chromatograms were developed.

2.6.2 Preparation of hydrogen peroxide induced degradation products

To $20 \mathrm{ml}$ each of the stock solutions of hydrocortisone, clotrimazole and synthetic mixture; $5 \mathrm{ml}$ of $3 \% \mathrm{v} / \mathrm{v} \mathrm{H}_{2} \mathrm{O}_{2}$ and $5 \mathrm{ml}$ of $30 \% \mathrm{v} / \mathrm{v} \mathrm{H}_{2} \mathrm{O}_{2}$ were added separately. The drug substances were allowed to react with the oxidant for 24 hours at room temperature. The resulting solutions were then heated in water bath for 6 hours to completely remove the excess of $\mathrm{H}_{2} \mathrm{O}_{2}$. The resultant solutions were applied on to HPTLC plate at $500 \mathrm{ng} / \mathrm{spot}$ level and the chromatograms were developed.

2.6.3 Preparation of thermal stress induced degradation products

A $20 \mathrm{mg}$ of each of hydrocortisone, clotrimazole and synthetic mixture were kept in an oven at $105^{\circ} \mathrm{C}$ for 16 hours. The synthetic mixture contains $20 \mathrm{mg}$ of each of hydrocortisone and clotrimazole. The chromatograms of the solutions were developed at $500 \mathrm{ng} / \mathrm{spot}$ level.

\section{RESULTS AND DISCUSSION}

3.1. Development of the optimum mobile phase

Among the different mobile phase combinations tested, Toluene:1Propanol:Ammonia (3: 13: 0.1) gave better resolution and sharper peaks with $\mathrm{R}_{\mathrm{f}}$ values of $0.27 \pm 0.01$ and $0.58 \pm 0.02$ for hydrocortisone and clotrimazole respectively. Figure 2A and Fig 2B show the UV spectra and the HPTLC chromatogram of the two drug mixture respectively using the optimal conditions. Well defined spots were obtained when the chamber was saturated with the mobile phase for $25 \mathrm{~min}$ at room temperature.
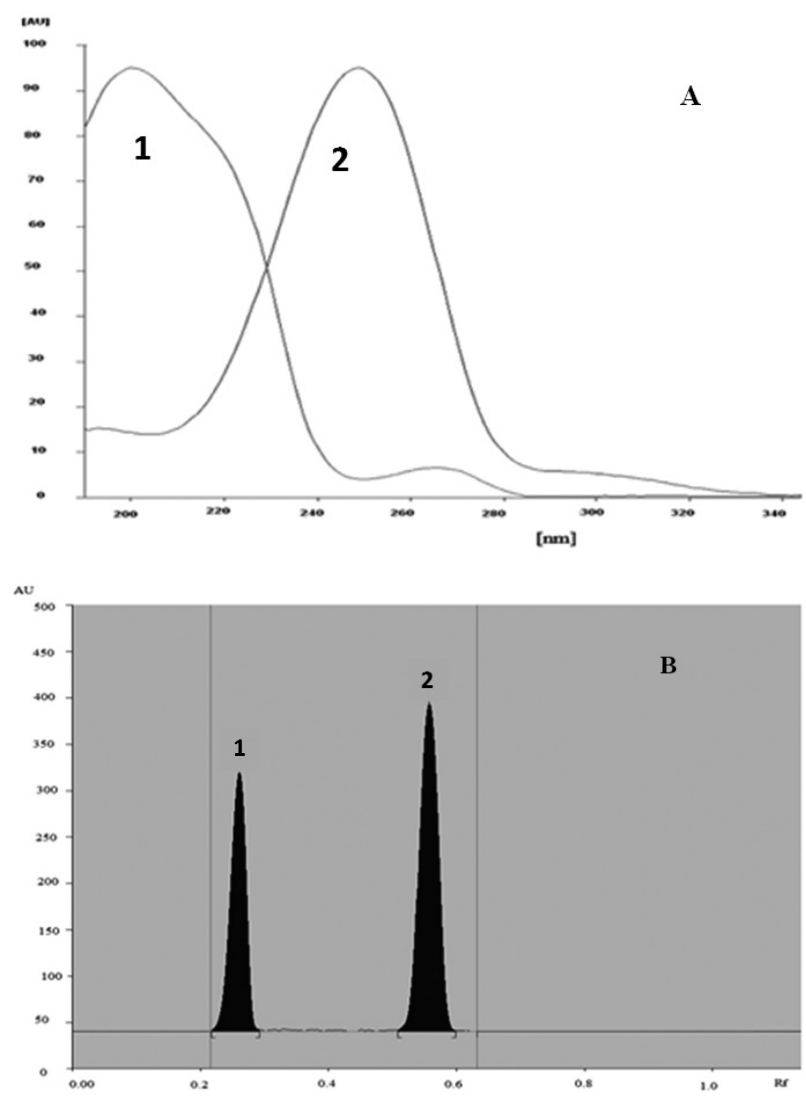

Fig.2: Spectral display of hydrocortisone (1) and clotrimazole (2) [A] and peak display for hydrocortisone (1) and clotrimazole (2) at $226 \mathrm{~nm}$ [B].

Validation of the method

3.1.1. Linearity

The concentration ranges of $200-1200 \mathrm{ng} / \mu 1$ and $200-1000 \mathrm{ng} / \mu \mathrm{l}$ were found to have good linear relationship with respect to peak area for hydrocortisone and clotrimazole. The curves were found to be linear in these ranges of concentrations and the correlations were suitable for quantitative determinations. Linear regression data is presented in Table 1.

Table 1: Summary of linear regression data $(n=3)$

\begin{tabular}{|c|c|c|}
\hline Parameters & Hydrocortisone & Clotrimazole \\
\hline Linearity range $(\mathrm{ng} / \mu \mathrm{l})$ & $200-1200$ & $200-1000$ \\
\hline $\mathrm{R}^{2} \pm \mathrm{SD}$ & $0.996 \pm 0.003$ & $0.9962 \pm 0.002$ \\
\hline Slope $\pm \mathrm{SD}$ & $4.34 \pm 0.28$ & $6.72 \pm 0.27$ \\
\hline Intercept $\pm \mathrm{SD}$ & $271.09 \pm 46.44$ & $719.64 \pm 71.17$ \\
\hline $\begin{array}{c}\text { Linear regression } \\
\text { equation }\end{array}$ & $\mathrm{Y}=4.3397 \mathrm{X}+271.09$ & $\mathrm{Y}=6.7228 \mathrm{X}+719.64$ \\
\hline
\end{tabular}


3.1.2 Precision

The intra- and inter-day variation for the determination of hydrocortisone and clotrimazole was carried out at the whole linearity range. Intra-day precision was obtained by analysing the same sample three times within one day. This was repeated on two different days by using freshly prepared samples and mobile phases. The results were reported as RSD for the peak area. The precise region of the linearity range was found to be $300-800 \mathrm{ng} / \mu \mathrm{l}$ for hydrocortisone and $400-800 \mathrm{ng} / \mu 1$ for clotrimazole (Table 2). The variation between analysts, as part of inter-day precision, was determined and evaluated (Table 3).

3.1.3 Accuracy

The proposed method when used for subsequent determination of hydrocortisone and clotrimazole in pharmaceutical dosage form after spiking with three levels of additional standard hydrocortisone and clotrimazole afforded a recovery value of $99 \%$ to $102 \%$, as shown in Table 4 . These values were found to be acceptable on evaluation using Howritz equation.

Table 2: Data for intra- and inter-day precision determination for hydrocortisone and clotrimazole. The results are presented as means $\pm \mathrm{SD}$ of six independent measurements.

\begin{tabular}{|c|c|c|c|c|c|}
\hline \multirow{2}{*}{ Substance } & \multirow{2}{*}{$\begin{array}{l}\text { Amount } \\
(\mathrm{ng} / \mu \mathrm{l})\end{array}$} & \multicolumn{2}{|c|}{ Intra-day precision $(\mathrm{n}=3)$} & \multicolumn{2}{|c|}{ Inter-day precision $(\mathrm{n}=3)$} \\
\hline & & Mean peak area (AU) & RSD & Mean peak area (AU) & RSD \\
\hline \multirow{6}{*}{ Hydrocortisone } & 300 & $1498.73 \pm 16.55$ & 1.10 & $1514.89 \pm 27.29$ & 1.80 \\
\hline & 400 & $1987.11 \pm 22.66$ & 1.14 & $1993.59 \pm 39.31$ & 1.97 \\
\hline & 500 & $2563.07 \pm 31.82$ & 1.24 & $2517.19 \pm 61.73$ & 2.45 \\
\hline & 600 & $2828.49 \pm 21.20$ & 0.75 & $2797.12 \pm 36.02$ & 1.29 \\
\hline & 700 & $3260.42 \pm 30.40$ & 0.93 & $3238.37 \pm 32.15$ & 0.99 \\
\hline & 800 & $3627.73 \pm 36.05$ & 0.99 & $3688.68 \pm 60.32$ & 1.64 \\
\hline \multirow{5}{*}{ Clotrimazole } & 400 & $3317.03 \pm 31.50$ & 0.95 & $3287.74 \pm 67.50$ & 2.05 \\
\hline & 500 & $3977.45 \pm 42.69$ & 1.07 & $3983.59 \pm 10.07$ & 0.25 \\
\hline & 600 & $4696.29 \pm 80.74$ & 1.72 & $4657.35 \pm 26.06$ & 0.56 \\
\hline & 700 & $5376.67 \pm 84.64$ & 1.57 & $5242.02 \pm 96.55$ & 1.84 \\
\hline & 800 & $6020.68 \pm 82.14$ & 1.36 & $5859.35 \pm 124.0$ & 2.13 \\
\hline
\end{tabular}

Table 3: Data for analyst variation study for hydrocortisone and clotrimazole. The results are presented as means $\pm \mathrm{SD}$ of six independent measurements.

\begin{tabular}{|c|c|c|c|c|}
\hline Analyst & Peak response of Hydrocortisone & RSD & Peak response of Clotrimazole & RSD \\
\hline Analyst-1 & $2592.2 \pm 18.72$ & 0.719 & $3981.54 \pm 33.40$ & 1.15 \\
\hline Analyst-2 & $2611.1 \pm 21.51$ & 0.826 & $3966.98 \pm 55.25$ & 1.89 \\
\hline Reference & $2615.3 \pm 35.24$ & 1.352 & $4031.7 \pm 59.27$ & 2.03 \\
\hline
\end{tabular}

Table 4: Data for recovery determination for hydrocortisone and clotrimazole.

\begin{tabular}{|c|c|c|c|c|c|c|c|}
\hline Substance & $\begin{array}{c}\text { Level of } \\
\text { addition (\%) }\end{array}$ & $\begin{array}{c}\text { Total amount } \\
(\mathrm{ng} / \mu \mathrm{l})\end{array}$ & $\begin{array}{c}\text { Amount of } \\
\text { reference added } \\
(\mathrm{ng} / \mu \mathrm{l})\end{array}$ & $\begin{array}{c}\text { Peak response } \\
(\text { average n=6) }\end{array}$ & $\begin{array}{c}\text { Amount recovered } \\
(\mathrm{ng})\end{array}$ & \% Recovery & RSD \\
\hline Clotrimazole & 80 & 400 & 50 & $3500.86 \pm 21.67$ & $49.57 \pm 0.61$ & $99.15 \pm 1.22$ & 1.23 \\
\hline & 100 & 500 & 150 & $4170.06 \pm 23.30$ & $149.12 \pm 1.63$ & $99.41 \pm 1.09$ & 1.09 \\
\hline & 120 & 600 & 250 & $4848.26 \pm 26.22$ & $250.00 \pm 4.01$ & $100.00 \pm 1.60$ & 1.60 \\
\hline Hydrocortisone & 80 & 400 & 50 & $1931.01 \pm 15.39$ & $49.72 \pm 0.92$ & $99.45 \pm 1.854$ & 1.86 \\
\hline & 100 & 500 & 150 & $2369.42 \pm 22.67$ & $150.75 \pm 2.23$ & $100.50 \pm 1.486$ & 1.47 \\
\hline & 120 & 600 & 250 & $2811.68 \pm 21.11$ & $252.65 \pm 4.31$ & $101.06 \pm 1.72$ & 1.70 \\
\hline
\end{tabular}

3.1.4 Specificity

The peak purity of hydrocortisone and clotrimazole was assessed by comparing the spectra at peak start, peak apex and peak end positions of the spot. The correlation for hydrocortisone at peak start and apex and at peak apex and peak end were found to be 0.9997 and 0.9996 respectively while the results were found to be 0.9995 and 0.9996 at peak start and apex and at peak apex and peak end respectively for clotrimazole. Since the values for both substances are close to one, the analyte chromatographic peak was not attributable to more than one component.
3.1.5 Robustness of the method

The low values of RSD obtained after introducing small changes in mobile phase composition also indicated robustness of the method as indicated in Table 5. 
Table 5: Data for robustness determination of the method for hydrocortisone and clotrimazole analysis.

\begin{tabular}{|l|l|l|l|l|}
\hline \multirow{2}{*}{ Parameters } & \multicolumn{2}{l|}{ Hydrocortisone } & \multicolumn{2}{l|}{ Clotrimazole } \\
\cline { 2 - 5 } & SD & RSD & SD & RSD \\
\hline Composition of mobile phase & 35.68 & 1.35 & 55.20 & 1.38 \\
\hline Time from spotting to development & 21.30 & 0.79 & 45.49 & 1.14 \\
\hline Time from development to scanning & 16.61 & 0.63 & 49.11 & 1.22 \\
\hline
\end{tabular}

Table 6: Data for the effect of mobile phase composition variation study on $\mathrm{R}_{\mathrm{f}}$ values of hydrocortisone and clotrimazole.

\begin{tabular}{|l|c|c|}
\hline \multirow{2}{*}{ Solvent system (V/V) } & \multicolumn{2}{|c|}{$\mathbf{R}_{\mathrm{f}}$ values } \\
\cline { 2 - 3 } & Hydrocortisone & Clotrimazole \\
\hline Toluene: Propanol: Ammonia (13:3:0.1)* & 0.27 & 0.58 \\
\hline Toluene:Propanol:Ammonia (11.7:3:0.1) & 0.28 & 0.57 \\
\hline Toluene:Propanol:Ammonia (14.3:3:0.1) & 0.24 & 0.59 \\
\hline Toluene:Propanol:Ammonia (13:2.7:0.1) & 0.23 & 0.55 \\
\hline Toluene:Propanol:Ammonia (13:3.3:0.1) & 0.28 & 0.61 \\
\hline Toluene:Propanol:Ammonia (13:3:0.09) & 0.26 & 0.55 \\
\hline Toluene:Propanol: Ammonia (13:3:0.11) & 0.25 & 0.56 \\
\hline
\end{tabular}

*= Optimized solvent system

\subsection{Analysis of dosage forms}

Applicability of the validated method for assaying of hydrocortisone and clotrimazole in the available pharmaceutical dosage form was investigated. The assay results for hydrocortisone and clotrimazole are presented in Table 7. The typical chromatogram (Figure 3A) for the analyzed dosage form showed that the peaks for both substances are similar in shape and $R_{f}$ values with those of the reference standards. The low RSD value indicated the suitability of this method for routine analysis of hydrocortisone and clotrimazole in pharmaceutical dosage form.

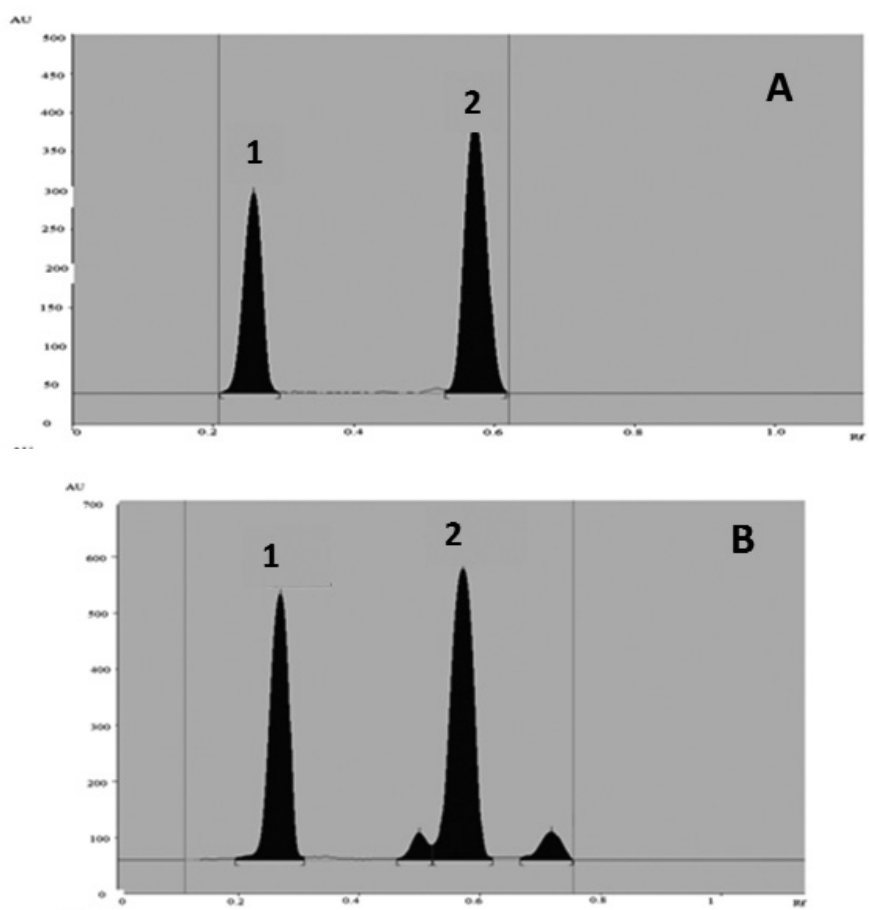

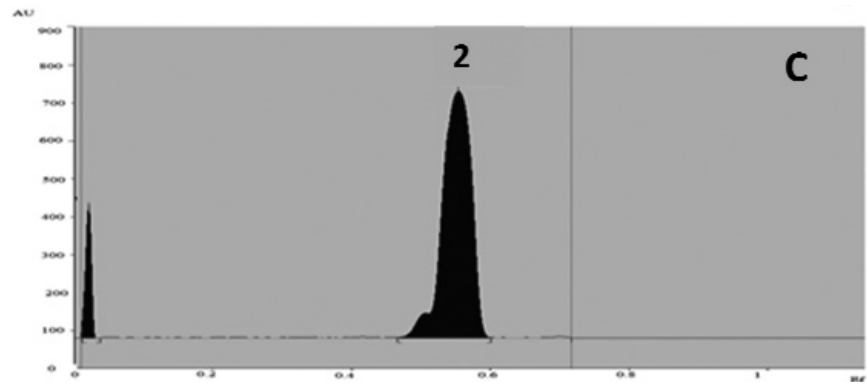
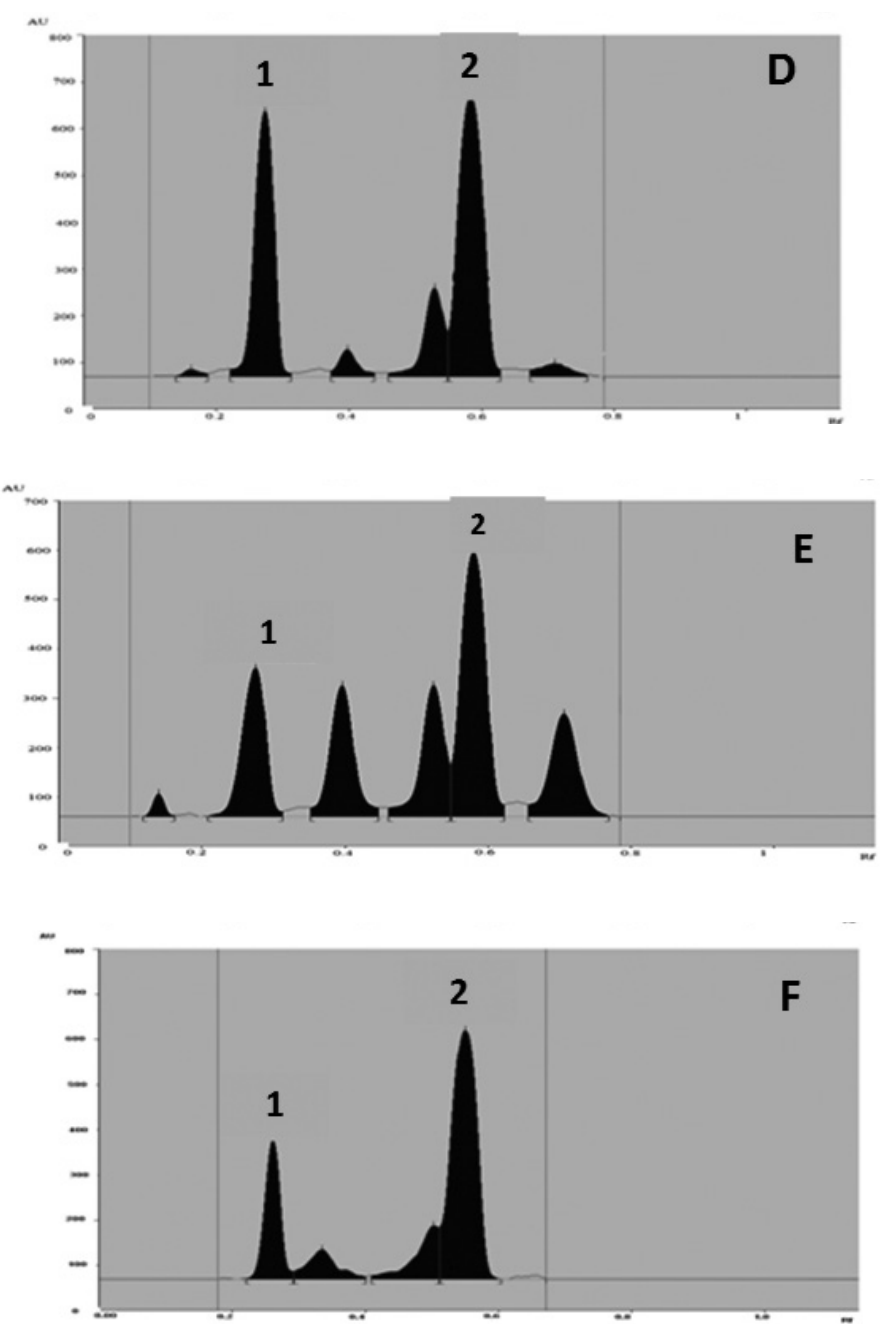

Fig. 3: Peak display of hydrocortisone (1) and clotrimazole (2) from the dosage form.(A) treated with $1 \mathrm{M} \mathrm{HCl}$ and heated under reflux at $80^{\circ} \mathrm{C}$ for 8 hr (B) treated with $1 \mathrm{M} \mathrm{NaOH}$ and heated under reflux at $80^{\circ} \mathrm{C}$ for $8 \mathrm{hr}(\mathrm{C})$ treated with $3 \% \mathrm{H}_{2} \mathrm{O}_{2}$ at room temperature (D) treated with $30 \% \mathrm{H}_{2} \mathrm{O}_{2}$ at room temperature (E) degraded thermally at $105^{\circ} \mathrm{C}$ for $16 \mathrm{hr}(\mathrm{F})$. 
Table 7: Assay determination for hydrocortisone and clotrimazole in candacort ${ }^{\mathbb{R}}$ cream

\begin{tabular}{|c|c|c|c|c|c|}
\hline Substance & $\begin{array}{c}\text { Amount } \\
\text { (ng/band) }\end{array}$ & Peak area (n=3) & $\begin{array}{c}\text { Amount found (ng/ } \\
\text { band) }\end{array}$ & \% Content \\
\hline Hydrocortisone & 508.98 & $2329.09 \pm 30.84$ & $474.22 \pm 7.10$ & $93.17 \pm 1.39$ & 1.50 \\
\hline & 513.49 & $2447.39 \pm 40.28$ & $501.48 \pm 9.28$ & $97.66 \pm 1.80$ & 1.85 \\
\hline & 497.77 & $2366.03 \pm 19.17$ & $482.73 \pm 4.41$ & $96.98 \pm 0.88$ & 0.92 \\
\hline & 506.7 & $2380.83 \pm 30.09$ & $486.14 \pm 6.93$ & $95.93 \pm 1.36$ & 1.83 \\
\hline Clotrimazole & 512.23 & $3960.01 \pm 40.12$ & $481.99 \pm 5.96$ & $94.09 \pm 1.16$ & 1.24 \\
\hline & 513.49 & $3979.92 \pm 61.14$ & $484.94 \pm 9.09$ & $94.44 \pm 1.77$ & 1.88 \\
\hline & 497.77 & $3925.74 \pm 10.35$ & $476.89 \pm 1.53$ & $95.80 \pm 0.30$ & 0.32 \\
\hline
\end{tabular}

\section{Stability indicating property}

It was observed that both drug substances were degraded on heating under reflux in $1 \mathrm{M} \mathrm{HCl}$ for $8 \mathrm{hr}$ at $80^{\circ} \mathrm{C}$ and also upon treatment with $3 \%$ and $30 \%$ hydrogen peroxide. Unlike hydrocortisone, clotrimazole was found to be resistant to degradation on heating under reflux in $1 \mathrm{M} \mathrm{NaOH}$ and thermal stress. The degradation products were clearly separated from the parent drugs.

\begin{tabular}{|l|l|l|l|}
\hline Ser. No & Sample exposure conditions & $\begin{array}{l}\text { Number of degradation products } \\
\text { with their } \mathrm{R}_{\mathrm{f}} \text { value }\end{array}$ & Figure \\
\hline 1 & Hydrocortisone, $1 \mathrm{M} \mathrm{HCl}$ & $1(0.51)$ & $3 \mathrm{~B}$ \\
\hline 2 & Clotrimazole, $1 \mathrm{M} \mathrm{HCl}$ & $1(0.72)$ & $3 \mathrm{~B}$ \\
\hline 3 & Hydrocortisone, $1 \mathrm{M} \mathrm{NaOH}$ & $2(0.02,0.52)$ hydrocortisone totaly degraded & $3 \mathrm{C}$ \\
\hline 4 & Clotrimazole, $1 \mathrm{M} \mathrm{NaOH}$ & Not degraded & $3 \mathrm{C}$ \\
\hline 5 & Hydrocortisone, $\mathrm{H}_{2} \mathrm{O}_{2}$ & $2(0.35,0.51)$ & $3 \mathrm{D}, 3 \mathrm{E}$ \\
\hline 6 & Clotrimazole, $\mathrm{H}_{2} \mathrm{O}_{2}$ & $3(0.11,0.48,0.68)$ & $3 \mathrm{D}, 3 \mathrm{E}$ \\
\hline 7 & Hydrocortisone, thermal & $2(0.34,0.51)$ & $3 \mathrm{~F}$ \\
\hline 8 & Clotrimazole, thermal & Not degraded & $3 \mathrm{~F}$ \\
\hline
\end{tabular}

\section{CONCLUSION}

The developed HPTLC technique is precise, specific and accurate. Statistical analysis proved that the method is repeatable and specific for the analysis of hydrocortisone and clotrimazole in bulk drug and in pharmaceutical formulations. As the method separated the drugs from their degradation products, it can be employed as a stability indicating one.

\section{REFERENCES}

1. Martindale, the extra pharmacopoeia, $31^{\text {st }}$ edn, The Pharmaceutical Society press, London, 1996

2. S. Van der Laan, O.C. Meije, Euro. J. of Pharmacol. 585: 483-491, (2008).

3. H. Schacke, W. Docke, K. Asadullah, Pharmacol. \& Thearp. 96: 23-43, (2002).

4. K. Betram Basic and clinical pharmacology, $10^{\text {th }}$ edn., Mc Graw Hill, USA, 2004.

5. C.M. Spies, J.W. Bijlsma, G.R. Burmester, F. Buttgereit, COPHAR. 10: $1-6,(2010)$.

6. R.U. Hengge, T. Ruzicka, R.A. Schwartz, M.J. Cork, J. Am. Acad. Dermatol. 54: 1-15, (2006).

7. K. Valerie, M. Vladmir, T. Paul, DMD, 29: 837-842, (2001).

8. G. Bartolommei, F. Tadini-Buoninsegni, S. Hua, M. Moncelli, G. Inesi, R. Guidelli, J. Biol. Chem. 28: 9547-9551, (2006).

9. T. Porsbring, H. Blanck, H. Tjellstrom, T. Backhaus, Aqua. Toxicol. 91: 203-211, (2009).

10. A.C. Moffat, J.V. Jackson, M.S. Moss, B. Widdop, Clark's identification of drugs in pharmaceuticals, body fluids and post mortem materials, $2^{\text {nd }}$ edition, The Pharmaceutical Press, London, 1986.

11. R. Hajkova, P. Solich, J. Dvorak, J. Sicha, J. Pharm. Biomed. Anal. 32: 921-927, (2003).
12. J. Gallego, and A.J. Perez, Anal. Chem. Act. 460: 85-97, (2002).

13. USP. National Formulary and the compendia of standards, vol $2,24^{\text {th }}$ edition, The united States Pharmacoepial Convention, Inc., Philadelphia, 2009.

14. BP. Formulated preparations, blood products, immunological products, radio pharmaceutical preparations, surgical materials, infrared reference spectra appendices and supplementary chapters index, British Pharmacopeia Commission, vol 2, 2004.

15. R. Earla, S.H. Boddu, K. Cholkar, S. Hariharan, J. Jwala, A.K. Mitra, J. Pharm. Biomed. Anal. 52: 525-533, (2010).

16. P. Khashaba, S. El-Shabouri, K. Emara, A. Mohamed, J. Pharm. Biomed. Anal. 22: 363-376, (2000).

17. F. Khalil, M. Ramin, J. Pharm. Biomed. Anal. 30: 1023-1033, (2002).

18. B. Vandana, D. Susan, N. Yogeeta, J. Pharm. Biomed. Anal. 25: 685-688, (2001).

19. Validation of analytical procedures. International Conference on Harmonization (ICH) of Technical Requirements for the Registration of Pharmaceuticals for Human Use, Geneva, 2005. (Accessed on 15/11/2009 and available at http://www.biologicsconsulting.com/docs/ich/ICHQ2B. pdf).

\section{ACKNOWLEDGMENTS}

The authors would like to thank the Egyptian Fund for Technical Cooperation with Africa, Ministry of Foreign Affairs, Egypt, for sponsoring the employment of Prof. Adnan Bekhit in the department of Pharmaceutical Chemistry, Addis Ababa University. 